\title{
Experts by Experience Infusing Professional Practices in Child Protection
}

\author{
Tarja Pösö
}

\section{Introduction}

In child protection, children's rights are embedded in the international conventions of human rights and, to a varying degree, in national legislation. In addition, they are also embedded in the ethical codes for social workers which guide their practice in child protection. Accordingly, social workers should respect human rights and human dignity, which is further specified to include the promotion of the right to participation. This is expressed by the International Federation of Social Workers as follows:

Social workers should promote the full involvement and participation of people using their services in ways that enable them to be empowered in all aspects of decisions and actions affecting their lives. (International Federation of Social Workers 2017)

\footnotetext{
T. Pösö $(\triangle)$

Faculty of Social Sciences, University of Tampere, Tampere, Finland e-mail: tarja.poso@uta.fi 
More specifically, according to Article 12 of the Convention on the Rights of the Child (CRC), children are entitled to the right to express their views in all matters affecting them, and their views should be considered. In society, children should be heard not only as individuals regarding the decisions of their personal life but also as groups of children representing the interests and needs of children in general in public decision-making (Tisdall and Davis 2004; Tisdall 2008; Marshall et al. 2015). Despite the strong legal and ethical incentives, children's participation is not easily translated from principle into effective practice (Tisdall and Davis 2004).

A common obstacle mentioned in literature is the view that children have a limited capability to participate in their own child protection cases due to their low age or diminished competencies (Bijleveld et al. 2015). Nevertheless, groups of children and young people exist who have successfully made a platform for their views to be heard, and fought against the presumptions about their lack of skills and competences. These groups are referred to as 'experts by experience in child protection'.

In Finland and elsewhere, these experts by experience have gained a strong foothold in child protection as in other areas of social welfare and health care services as they present their views in the political arenas and operate for self-help purposes (Noorani 2013; Meriluoto 2016; Toikko 2016). This is reflected, among other things, in the review of the state of child protection by the Ministry of Social Affairs and Health in Finland. The first of the 54 recommendations states that the Child Welfare Act should be revised to include a paragraph about the experts by experience so that the municipalities, which are responsible for providing child protection services, should involve them to instruct their service-provision (Toimiva lastensuojelu 2013, p. 69). By such measures the experts by experience have indeed been put on the front line of developing child protection services and providing relevant knowledge. Consequently, the argument in this chapter is that the very position given to, and taken by, experts by experience is not only about involvement and the right for participation but about knowledge as well. The inclusion of the experts by experience is also about the very way we can know about child protection and children's rights. This chapter examines what kind of view on the right to participation the experts by experience promote and how 
their experiential knowledge influences child protection practice and related knowledge production.

The chapter will focus on one group of experts by experience, 'Selviytyjät', henceforth referred to by their English name of 'the Survivors'. There are two reasons for this: first, their long period of activism has grounded the Survivors' activities explicitly in children's right to participate; second, they have made their statements public in different forms-videos, publications and information sheets-which provide rich data for this essay. I will look at four of their documents and the ideas they present about children's right to participation in child protection. I will also track their influences on different arenas of child protection: national legislation and guidelines, policy documents as well as social work practice. The latter task is supported by my long involvement in Finnish child protection as a teacher and researcher as well as by being an observer and an occasional participant of the Survivors' activities. As will be demonstrated later, their input is, indeed, far from the tokenism which sometimes describes the superficial involvement of children in policy and practice (Tisdall and Davis 2004; Hart 1992). Their rationale will be presented after a short discussion of the definition of experts by experience.

\section{Experts by Experience: Focus on Expert and Experiential Knowledge}

The term 'experts by experience in child protection' (lastensuojelun kokemusasiantuntija) is widely used in child protection policy and practice although it does not have a fixed meaning in the Finnish context nor in international research literature (McLaughlin 2009). It generally refers to service-users of child protection services that share their experiences more or less publicly in order to inform and influence other service-users, service-providers, decision-makers, policymakers and other interested parties. They may be children who presently receive services or young adults who have left the child protection system. Experts by experience may function individually or in groups. There are no explicit criteria as to 
how much — or what kind of - insider experience one should have, but often the child protection experts by experience are children who have been taken into care and thereby have substantial experience.

As a term, 'experts by experience' differs from 'service users'. This difference is important to acknowledge because the terms define and construct identities, relationships, roles and positions in the welfare system (Hübner 2014). The focus on knowledge and expertise differentiates the term 'expert by experience' from that of a 'service-user' in which the use of services and the binary positions of service-user and service-provider are emphasized. The term 'experts by experience' 'makes a claim for specialist knowledge base rooted in an individual's experience of using services' as stated by McLaughlin (2009); thus, in order to become an expert by experience, one needs to have serviceuser experiences (Toikko 2016). The term defines the nature of expertise to be based on experience and thereby differentiates it from expertise gained otherwise (through formal education for example). It does not state that this expertise is less or more valuable than 'formal' expertise; it is just a quality of expertise cherishing a postmodern view on expert knowledge in which the authority of professionals as experts is challenged (Scourfield 2010). Rather it suggests 'a relationship of equals whereby one expert's position has been gained through their training and practice and the other through their experience' (McLaughlin 2009) and that 'experiential authority' exists in addition to 'traditional authority' (Noorani 2013).

As in any form of user-involvement in social and health care, the expertise of experts by experience is by its nature experiential knowledge (e.g. Beresford and Croft 2001). Experiential knowledge is a distinctive form of particularizing knowledge. It emphasizes everyday life and is sometimes addressed as a 'science of everyday life' (Gubrium 2016). Although experiential knowledge has been recognized before in the literature of social work knowledge, what is new is that experiential knowledge has become strongly incorporated into policymaking and its implementation, especially as a result of the user-involvement movement (Gubrium 2016; Beresford and Croft 2001). It has moral bearings of its own: it emphasizes the experiences of an individual, and challenges — and even contests-knowledge from formal education, qualifications and 
research. Indeed, the very positions of experts, formal knowledge and professional problem constructions are challenged by experiential knowledge (Beresford 2013; Järvinen 2016; Alm Andreassen 2016; Meriluoto 2016).

Child protection practice, on the other hand, aims to strengthen its evidence base, to be informed by research and related 'formal' knowledge (Shlonsky and Benbenishty 2014). In addition, formal qualifications are expected from people who carry out tasks in statutory child protection. Finnish social workers should be licensed to have the right to work in child protection. In order to gain the licence, they must have completed five years of university studies, including social work studies, culminating in a master's degree. The base for formal knowledge is further guided by legislation which, among many other issues, defines the rights entitled to children and the obligations for social workers and municipalities. Consequently, the experiential knowledge of experts by experience is practised in conjunction with the requirements for formal knowledge in statutory child protection.

\section{The Expert Views from Inside: Survivors' Messages}

The distinctive period of experts by experience in child protection goes back as far as the mid-2000s in Finland. A particular landmark occurred in 2008 when one NGO, Pesäpuu ry, organized a group of young people experiencing care to inform practitioners about the key issues in child protection as experienced from inside. This group of 10 young women was called 'Selviytyjät'. Later it expanded considerably and similar groups were established in different parts of Finland. At the end of 2016, these groups of children and young people, estimated to be about 20 in number, formed a national network to inform and support each other and to work collectively in their activities to influence and develop child protection policy and practice (Barkman et al. 2017). Some groups involve young children-between the ages of 3 and 8 -but the majority of the groups involve teenagers or young adults. 
Over the years, the experts by experience have created a distinctive social forum for the recognition of personal experiences of children in care. The messages of the Survivors are listened to in many arenasnational and local child protection conferences, government programmes and steering groups, legislative initiatives and the media. In 2017, the count of public talks was 611,000 and the number of published statements was 50,000 since the establishment of the Survivors (Barkman et al. 2017, p. 12). The volume of their public statements is considerable in a country of 5.4 million inhabitants. In addition to these public activities, the Survivors have small peer-group meetings, sharing intimately personal experiences as well as larger meetings with the aim of formulating the shared messages based on their insider experiences, and projects with specific tasks (such as preparing interview tools for practitioners for interacting with teenagers). In order to learn about the contents of the messages of the Survivors, I will look more closely at four of their key documents.

\subsection{Listen to Children in Care}

The first of these is a web-based publication summarizing the key messages of children, the outcome of the first national gatherings of children in care under the umbrella of expertise by experience in 2010. Most attention is given here to dreams - that children in care have the right to dream about their future and things which are important to them. It is also stated that the professionals should listen to the child and meet her with time and dedication - a message similar to research literature on children's views on professionals (e.g. Hill 1999). It also summarizes the aim for their activities in the following way (a translation of the original text):

The more adults listen to the experiences of young people and see their eagerness to make a change, the more responsible adults are in promoting the issues relevant to young people. That is why politicians and decision-makers should also listen to children in care. (Minä selviydyn 2010)

The publication states that the more adults—social workers, politicians and decision-makers - hear children's insider views and see their interest 
in making an impact, the more responsibly adults would act. It is stated elsewhere in the publication that the involvement of the experts by experience follows the principles of the United Nations Convention on the Rights of the Child (CRC). In this way, the experts by experience position themselves as a group influencing policy, service-development, practice and legislation. This formulation is a strong statement about the public nature of the insider views and experiences (e.g. McNeish 1999).

\subsection{Know Your Rights and Responsibilities}

The second public statement to present here is a booklet, 'We believe in you — so should you', which was published in 2010, first in Finnish and later in Swedish and English. It was written 'to children in care from children in care' as stated in the document. It included information about children's rights and child protection. Its task is described as follows:

The title of this book was inspired by our experiences: when we were placed in substitute care, we did not believe in ourselves. We badly needed someone to believe in us. We hope this book will help you to understand your life situation better and to make it through the days to come!

This book is your personal guide to the world of child welfare. There is lots to read here. Read one page at a time and reflect on it. Take some time to digest what you have read. Make notes, tick the boxes and answer the questions. If you feel like it, ask a grown-up to help you. Ask him or her for advice and for more information on things you don't understand.

Know your rights and responsibilities and act according to them. ${ }^{1}$

There is a strong empowerment element in this description: it opens a rights-based approach to being in care. Shared experiences are described as being a shared strength—that is 'why we trust in you'.

\section{3 'We-Talk' as an Ethical Choice}

The third document, the code of ethics for participation, was published in 2014 (Hipp and Palsanen 2014). The focus is widely on children's and 
young people's participation in developing services for children and young people. The code includes ten principles of ethical awareness. It also points out that children and young people might need to be protected from the media and other public arenas. Therefore, the Survivors' introduced 'we-talk', which is primarily about 'us' instead of 'me'. The selection of the 'we'-messages is typically done in groups: the individual and unique experiences are selected, thematically grouped, reworded and presented as collective experiences to outsiders (Barkman et al. 2017, pp. 27, 44).

\subsection{Changing the View from Problems to Strengths}

The fourth document was published in 2017: the book 'Muutosvoimaa' (Barkman et al. 2017) summarizes the experiences gained during the years of expertise by experience in child protection and instructs professionals and policymakers how to include experts by experience in their practice. It is also written for children and young people who are thinking of becoming experts by experience (ibid.). Although the book with its 63 pages covers many topics, the underlying message is that children's involvement can make a change in child protection and such involvement has already started making a change. It states that when children have been involved and when they have been listened to, the view on children has shifted from being problem-focused to strengths-based in policy and practice.

The published materials and the documents presented above total only a small fraction of the activities of the Survivors as the majority of activities take place in face-to-face interaction among themselves as well as with practitioners and policymakers. Nevertheless, in sum, when reading the documents, the overarching message is that children and young people want to - and need to- - be heard, trusted and involved based on their experiences of child protection, and that they should be seen as individual human beings instead of abstract clients or service-users. Their translation of Article 12 of the CRC into practice is thus see melus, hear me/us, learn to know melus and trust melus. 


\section{Experiential Knowledge on Rights: Influences and Contradictions}

The experiential knowledge of experts by experience is grounded in individual experiences and people's - children or young people who have experienced care-willingness to talk about their lives. This is embedded in present society, which Plummer (2001, p. 79) describes as being an 'auto/biographical society'. According to him, life stories are everywhere and they 'come in many forms, shifting across time and space' (Plummer 2001, p. 79). He also states that sometimes stories are silenced and other times they speak volumes: thus storytelling as well as listening to the stories are selective. Individualization in its typical form for late modernity emphasizes the self-realization of its members, including children, and a decline in the authority of expert knowledge (Prout 2000). When 'telling a life' includes face-to-face interaction, either directly or via the media, the likelihood increases that the stories will be listened to; this is also the case for the stories based on experiences of child protection (Marshall et al. 2015, p. 377). Hearing the views directly from children brings an individual and human element to the topics policymakers and practitioners are dealing with (ibid.).

\subsection{Experiential Knowledge Influencing Policy and Legislation}

The very characteristic of the experiential knowledge of being human and presented directly, and thus highly valued and prioritized in auto/ biographical society, was vividly demonstrated in the seminar organized by the Finnish Ministry of Social Welfare and Health in 2016. The seminar issued the state's apology for the historic abuse which had taken place in substitute care during the years of the first Child Welfare Act (1936-1983). The apology followed a research report exploring the maltreatment experiences of people placed in residential and foster care during that period of time (Hytönen et al. 2016). The report itself and the ensuing interest in the quality of substitute care was unique in the Finnish history of child protection. After the study had been presented, 
including 300 interviewees, two sessions with experts by experience were a part of the programme. This event thus comprised two different views on the experiences of child protection: the experiences gathered by a research team and its scientific rationale including the reflection of selection biases, validity and generalizability, and the face-to-face experiences by the experts by experience. In addition to the knowledge of historic abuse, the message of the programme was that, first, the direct experiences of experts are important in the public arena of child protection, and second, the knowledge gained through research is not sufficient on its own to inform about historic abuse and suggest the ways ahead. The third and more hidden message was that the knowledge of the previous or present practitioners is not needed to inform-and to make sense of - the extent and nature of historic abuse.

This event could be seen as a gesture to bring children's and young people's views into policymaking with regard to a delicate topic (Tisdall and Davis 2004). The experts by experience contributed to the seminar despite the difficulties of voicing experiences that are shadowed by taboos, losses or private emotions as well as structural violence (e.g. Farmer et al. 2013). The tragedy is, however, that what seems to follow from the recognition of historic abuse is rather contradictory in policy and practice as the plans to monitor the quality of substitute care tend to decrease the obligations for the public agencies in this regard. As a result, in November 2017, a group of experts by experience in child protection, including the Survivors, contacted the Ministry of Social Welfare and Health to ask for more statutory and systematic monitoring of substitute care services. In their public statement (Kannanotto ... 2017) their view was that the plans to increase in-house monitoring and decrease the monitoring duties of child protection authorities would be against the rights of children in care, and in fact, against the findings and recommendations of the report of historic abuse, and would further threaten children's safety in care. They do suggest that they could be involved in monitoring the quality of substitute care as peer-reviewers but that this should not diminish the duties of the public authorities.

This contradictory outcome of the official apology makes one wonder how the messages by the experts by experience have been received in child protection practice and policy as, on the one hand, the experts are 
given the floor in most important events, and on the other, the serviceusers' claims for protection in care are somewhat neglected.

There is no straightforward measure to capture these influences. Finland changed its child protection legislation in 2007 so that children's rights, especially participatory rights, were included in legislation, and consequently, on the legislative level, the Finnish child protection system has been and can be described as being orientated towards child-centrism in cross-country comparisons (Gilbert et al. 2011). In this context, the Survivors and other experts by experience have actively influenced policy programmes and even legislative changes: their experiential knowledge has indeed informed recent policy and legislation. The request for being met as a person ('see me, listen to me, trust me') by a social worker, for example, was reflected in the Child Welfare Act which introduced a new paragraph in 2013 stating that the social worker should meet the child in person often enough and that the meetings should be recorded in the case files to demonstrate that they have taken place $(\$ 29)$. This change in legislation is supported in the planning stages by the references to the statements given by the experts by experience saying that they have too few opportunities to meet their social workers (e.g. HE 130/2013).

In addition, when the national quality recommendations for child protection were introduced by the Ministry of Social Affairs and Health in 2014, they emphasized the importance of involving children individually in any part of the process of child protection as well as involving children to develop the services at the local level (Lastensuojelun laatusuositus 2014). The latter recommendation is the same as suggested by the committee established by the Ministry of Social Affairs and Health to review the state of child protection (Toimiva lastensuojelu 2013). However, the gap between legislation and the front-line practice of child protection regarding children's rights to have their views heard has been noted by research: practice does not in every respect include children in the same way as the legislation requires (e.g. de Godzinsky 2014; Toivonen 2017; Pösö and Enroos 2017). In this contradictory context, the Survivors and other experts by experience have merged together the general principles of the CRC, and Article 12 in particular, as well as their own wishes and needs, with more diffuse influences on the practice than on the policy level. 


\subsection{The Inclusion of Children's Views in Front-Line Practice}

The front-line practice of child protection is currently influenced not only by the CRC but also by the cost-awareness of public expenditure and the privatization of child protection services. This creates an obvious tension, widely experienced by social workers, between the wishes and needs of the experts by experience, the CRC, the norms towards human child protection and the ethical principles of the profession to respect human rights and dignity (Alhanen 2014). Social workers have expressed their concerns about their working conditions: heavy caseloads, lack of qualified staff and resources as well as lack of support in the organizations, all of which hinder them from working in the manner which would meet the ethical and professional standards of good social work (van der Mänttäri-van der Kuip 2016). In the six largest Finnish towns, social workers are estimated individually to work with 59 children on average (Ahlgren-Leinvuo 2016, 33); according to anecdotal knowledge the number may occasionally exceed more than 100 children. This is to say that the working conditions in child protection are not suited to support social work in the manner suggested by the experts by experience. Finnish social workers experience moral conflicts and distress as they cannot do their work in a morally sustainable way (Mänttäri-van der Kuip 2016). Social workers' knowledge of the fulfilment of children's rights—or a lack thereof-is, however, not highly valued in the public arenas of child protection (Alhanen 2014; Mänttäri-van der Kuip 2016).

Indeed, if the ideas of experts by experience are taken seriously, they would challenge the fundamental rationale and organizational design of child protection services. Cecilie Basberg Neuman (2016) writes about the request for love, expressed by the experts by experience in child protection in the Norwegian context, and how it challenges the foundations of professionalism and welfare state services. She argues, very wisely, that

... an unproblematised requirement that child protection workers must provide children with parent-like love may intersect with a current neoliberal international tendency towards de-professionalisation, that may 
have problematic consequences for both providers and recipients of care in the child protection services. (Basberg Neuman 2016)

Instead of asking social workers to love, in her view, it would be important to secure training, supervision and the emotional well-being of social workers so that they could provide children with good professional care (Basberg Neuman 2016). The claims and wishes of experts by experience should be transformed into practices which recognize the conditions of professional work provided by the state to improve the good quality of social work instead of de-professionalising it. This implies that there might be a need to critically reflect the implications drawn from the experiential knowledge of children's rights.

The experiential knowledge of children about the fulfilment of their rights is, by its very nature, individualistic, human and 'particularizing knowledge' (Gubrium 2016) and thereby selective. It does not concern itself with the social conditions and structures in which the experiences are embedded and rights practised. The risk in following only the knowledge given by the experts by experience is that the social conditions supporting or hindering the fulfilment of the rights are ignored. Human rights in child protection are, after all, materialized in social practices (Ife 2001; Clark 2002).

\section{$5 \quad$ Summing Up}

We have seen above that the recognition of children's rights, views and wishes owes a lot to the experts by experience in child protection. They have shaped the overall way of addressing child protection issues so that Article 12 of the CRC and the experiences of children are paid more attention to. This is especially obvious in the public arenas of policymaking whereas the impact on the front-line child protection practices is more diffuse. The social workers do widely share the mission of the experts by experience based on their ethical principles and legislation that guide their work. We have, as well, seen above that the implementation of rights-based practice is not straightforward as practice is influenced by 
many other factors as well—such as the very organization of the services and its resources.

What the Finnish case demonstrates is that more than the inclusion of experts by experience is required to make a change for better implementation of the CRC in child protection. We also need to focus on the overall social and moral conditions in which child protection takes place and the very notion of knowledge. The analysis above suggests that even more than before, there is a need also for formal and research-based knowledge in child protection as the experts by experience have highlighted the extreme complexity in putting children's rights into practice. The challenge is how to recognize, balance and value the different types of expertise and experts in child protection, and to put them into practice wisely with regard to the CRC.

\section{Notes}

1. http://www.pesapuu.fi/media/uploads/dokumentit/nuoret/we_believe_ in_you_so_should_you.pdf

\section{References}

Ahlgren-Leinvuo, H. (2016). Kuuden suurimman kaupungin lastensuojelun palvelujen ja kustannusten vertailu vuonna 2015 [The comparison of child welfare services and costs in 2015 among the six largests towns]. Kuusikkotyöryhmä. Retrieved from http://www.kuusikkokunnat.fi/SIRA_Files/downloads/Lastensuojelu2015_06102016.pdf

Alhanen, K. (2014). Vaarantunut suojeluvalta-Tutkimus lastensuojelujärjestelmän uhkatekijöistä [Compromised power of protection-A study of threats to the child welfare service system] (Report 24). Helsinki: Terveyden ja hyvinvoinnin laitos.

Alm Andreassen, T. (2016). Professional intervention from a service user perspective. In J. Gubrium, T. Andreassen, \& P. K. Solvan (Eds.), Reimagining the human service relationships (pp. 34-58). New York: Columbia University Press. 
Barkman, J., Inkinen, H., Isoniemi, S., \& Vario, P. (2017). Muutosvoimaa! Kohti nuorten kokemusasiantuntijuutta lastensuojelussa [Change power! Towards the expertise of young people in child welfare] (Opas- ja käsikirja 3). Jyväskylä: Pesäpuu ry.

Basberg Neuman, C. (2016). Children's quest for love and professional child protection work: The case of Norway. Scottish Journal of Residential Child Care, 15(3), 103-123.

Beresford, P. (2013). From 'other' to involved: User involvement in research: An emerging paradigm. Nordic Social Work Research, 3(2), 139-148.

Beresford, P., \& Croft, S. (2001). Service users' knowledges and the social construction of social work. Journal of Social Work, 2(1), 295-316.

Bijleveld, G., Dedding, C., \& Bunders-Aelen, J. (2015). Children's and young people's participation within child welfare and child protection services: A state-of-the-art review. Child \& Family Social Work, 20, 129-138.

Clark, C. (2002). Identity, individual rights and social justice. In R. Adams, L. Dominelli, \& M. Payne (Eds.), Critical practice in social work (pp. 38-45). Basingstoke: Palgrave Macmillan.

De Godzinsky, V. (2014). Lapsen etu ja osallisuus hallinto-oikeuksien päätöksissä [The child's best interest and participation in administrative court decisions] (Report 267). Helsinki: Oikeuspoliittinen tutkimuslaitos.

Farmer, E., Selwyn, J., \& Meakings, S. (2013). 'Other children say you're not normal because you don't live with your parents'. Children's views of living with informal kinship carers: Social networks, stigma and attachment to carers. Child \& Family Social Work, 18(1), 25-34.

Gilbert, N., Parton, N., \& Skivenes, M. (Eds.). (2011). Child protection systems. International trends and orientations. New York: Oxford University Press.

Gubrium, J. (2016). From the iron cage to everyday life. In J. Gubrium, T. Andreassen, \& P. Solvan (Eds.), Reimagining the human service relationships (pp. 3-32). New York: Columbia University Press.

Hart, R. (1992). Children's participation: From tokenism to citizenship. Florence: UNICEF. Retrieved from http://www.unicef-irc.org/publications/100

HE 130/2013. Hallituksen esitys eduskunnalle laiksi lastensuojelulain 28 \$:n muuttamisesta [Government Proposal concerning the the change of the paragraph 28 in Child Welfare Act]. Retrieved 7 December 2017, from http:// www.finlex.fi/fi/esitykset/he/2013/20130130

Hill, M. (1999). What's the problem? Who can help? The perspectives of children and young people on their well-being and on helping professionals. Journal of Social Work Practice, 13(2), 135-145. 
Hipp, T., \& Palsanen, K. (2014). Lasten osallistumisen etiikka-Lapset ja nuoret palveluiden kehittäjinä [The ethics of children's participation-Children and young people as developers of services]. Helsinki: Lastensuojelun keskusliitto. Retrieved on 15 March 2017, from https://www.lskl.fi/materiaali/ lastensuojelun-keskusliitto/Lasten_osallistumisen_etiikka1.pdf

Hübner, L. (2014). Constructing relations in social work: Client, customer and service user? The application and relevance of the term user in social work discourse. Nordic Social Work Research, 4(2), 87-98.

Hytönen, K., Malinen, A., Salenius, P., Haikari, J., Markkola, P., Kuronen M., \& Koivisto, J. (2016). Lastensuojelun sijaishuollon epäkohdat ja lasten kaltoinkohtelu 1937-1983 [The failures and abuse of children in substitute care 1937-1983] (Report 22). Helsinki: Sosiaali- ja terveysministeriö.

Ife, J. (2001). Human rights and social work. Towards rights-based practice. New York: Cambridge University Press.

International Federation of Social Workers (2017). Statement of ethical principles. Retrieved from: http://ifsw.org/policies/statement-of-ethical-principles/ on 10 December 2017.

Järvinen, M. (2016). Expertise and ambivalence in user-focused human service work. In J. Gubrium, T. Andreassen, \& P. Solvan (Eds.), Reimagining the human service relationships (pp. 59-78). New York: Columbia University Press.

Kannanotto sijaishuollon valvonnan säilyttämiseksi (2017). A claim to keep the monitoring of substitute care. Retrieved 14 December 2017, from http:// pesapuu.fi/media/uploads/dokumentit/kannanotto_sijaishuollon_ valvonnan_s\%C3\%A4ilymiseksi.pdf

Lastensuojelun laatusuositus [Quality recommendations for child welfare]. 2014. Report 4. Helsinki: Sosiaali- ja terveysministeriö.

Mänttäri-van der Kuip, M. (2016). Moral distress among social workers: The role of insufficient resources. International Journal of Social Welfare, 25(1), 86-97.

Marshall, C., Byrne, B., \& Lundy, L. (2015). Children and young people's right to participate in public decision-making. In T. Gal \& B. Duramy (Eds.), International perspectives and empirical findings on child participation (pp. 357-380). New York: Oxford University Press.

McLaughlin, H. (2009). What's in a name: 'Client', 'patient', 'customer', 'consumer', 'expert by experience', 'service-user'-What's next? British Journal of Social Work, 38(6), 1101-1117.

McNeish, D. (1999). Promoting participation for children and young people: Some key questions for health and social welfare organisations. Journal of Social Work Practice, 12(2), 191-203. 
Meriluoto, T. (2016). Kokemusasiantuntijuus ohjaavana ja voimaannuttavana hallintana [Expertise by experience as a form of ruling and empowering governance). In M. Nousiainen \& K. Kulovaara (eds), Hallinnan ja osallistamisen politiikat [The policies of governance and involvement] (pp. 65-96). Jyväskylä: Sophi.

Minä selviydyn. Nuoret Nuorille sijaishuollon foorumi Jyväskylä 17.11.2010. [I survive. From young people to young people]. Retrieved 14 June 2017, from http://pesapuu.fi/media/uploads/dokumentit/nuoret/nf2010.pdf

Noorani, T. (2013). Service user involvement, authority and the 'expert-byexperience' in mental health. Journal of Political Power, 6(1), 49-68.

Plummer, K. (2001). Documents of life 2. An invitation to a critical humanism. London: Sage.

Pösö, T., \& Enroos, R. (2017). The representation of children's views in the Finnish court decisions of care orders. International Journal of Children's Rights, 25(3-4), 736-753.

Prout, A. (2000). Children's participation: Control and self-realisation in British late modernity. Children \& Society, 14(4), 304-315.

Scourfield, P. (2010). A critical reflection on the involvement of 'experts by experience' in inspections. British Journal of Social Work, 40(1), 1890-1907.

Shlonsky, A., \& Benbenishty, R. (2014). From evidence to outcomes in child welfare. New York: Oxford University Press.

Tisdall, K. (2008). Is the honeymoon over? Children and young people's participation in public decision-making. International Journal of Children's Rights, 16(3), 419-429.

Tisdall, K., \& Davis, J. (2004). Making a difference? Bringing children's and young people's views into policy-making. Children \& Society, 18(2), 131-142. Toikko, T. (2016). Becoming an expert by experience: An analysis of service users' learning process. Social Work in Mental Health, 14(3), 292-312.

Toimiva lastensuojelu. (2013). Selvitysryhmän loppuraportti [Functioning child welfare. The final report] 2013 (Raportteja ja muistioita 2013:19). Helsinki: Sosiaali- ja terveysministeriö.

Toivonen, V.-M. (2017). Lapsen oikeudet ja oikeusturva. Lastensuojeluasiat hallintotuomioistuimissa [Children's rights and legal safety-Child welfare cases in administrative courts]. Helsinki: Alma Talent.

We believe in you-So should you. Retrieved 16 January 2017, from http:// www.pesapuu.fi/media/uploads/dokumentit/nuoret/we_believe_in_you_ so_should_you.pdf 
Open Access This chapter is licensed under the terms of the Creative Commons Attribution 4.0 International License (http://creativecommons.org/licenses/ by/4.0/), which permits use, sharing, adaptation, distribution and reproduction in any medium or format, as long as you give appropriate credit to the original author(s) and the source, provide a link to the Creative Commons license and indicate if changes were made.

The images or other third party material in this chapter are included in the chapter's Creative Commons license, unless indicated otherwise in a credit line to the material. If material is not included in the chapter's Creative Commons license and your intended use is not permitted by statutory regulation or exceeds the permitted use, you will need to obtain permission directly from the copyright holder.

(c) 